\title{
Empowerment of Tribal Women through Desi Chicken Enterprise in Ayodhyapattinam Block of Salem District in Tamil Nadu, India
}

\author{
N. Sri Balaji ${ }^{1 *}$, P. Ravi ${ }^{2}$ and D. Jayanthi ${ }^{3}$ \\ ${ }^{1}$ Mecheri Sheep Research Station, Pottaneri - 636 453, India \\ ${ }^{2}$ Veterinary University Training and Research Centre, Dharmapuri- 636 703, India \\ ${ }^{3}$ Veterinary University Training and Research Centre, Salem - 636 001, India \\ *Corresponding author
}

\section{A B S T R A C T}

\begin{tabular}{|l|}
\hline Key w o r d s \\
$\begin{array}{l}\text { SBGF, Desi bird } \\
\text { enterprise, } \\
\text { Ayodhyapattinam } \\
\text { block, Salem }\end{array}$ \\
\hline Article Info \\
\hline $\begin{array}{l}\text { Accepted: } \\
18 \text { April } 2020 \\
\text { Available Online: } \\
\text { 10 May 2020 }\end{array}$ \\
\hline
\end{tabular}

Desi bird rearing is a beneficial enterprise, nursing regular income and livelihood of tribal women farmers. The project entitled "Empowerment of tribal women by developing desi chicken enterprise in Salem District" was funded by State Balanced Growth Fund, Tamil Nadu (SBGF) and implemented by Veterinary University Training and Research Centre, Salem at Chinngoundapuram village, Ayodhyapattinam block, Salem District. The activities such as imparting training and technical guidance to the beneficiaries of the scheme, procurement and supply of inputs such as birds, cages, feed and egg incubator along with power back up were carried out by Veterinary University Training and Research Centre, Salem. A total of 50 tribal women were selected from Chinnagoundapuram village and formed into 5 common livelihood Groups. Total number of birds alive at the end of one year was $3.88 \pm 0.10$ out of six birds supplied to each beneficiary. The age (days) at laying first egg was $160 \pm 1.34$. Hatchability (\%) of eggs using egg incubator was $73.12 \pm 1.30$. The overall bird mortality (\%) was $22.12 \pm 2.12$. Monthly additional income per family was INR $1450 \pm 37$. It was concluded that the desi bird rearing is a very beneficial enterprise, ensuring additional regular income and plays the major role in empowering tribal women.

\section{Introduction}

Desi bird rearing is a beneficial enterprise, ensuring regular income and livelihood of tribal women farmers. There is evidence that investments in small- scale poultry farming generate handsome returns and contribute to poverty reduction and increased food security in regions where a large share of the population keeps some poultry birds (Jensen and Dolberg, 2003; Mack, et al., 2005; Pica- Ciamarra and Otte, 2010; Jha and Asit chakrabarti, 2017). There is also growing evidence to demonstrate the role of rural poultry farming in enhancing the food and nutrition security of the poorest households, 
reducing the livelihood vulnerability and insecurity and promotion of gender equity (Ahuja and Sen, 2007). Ayodhyapattinam block in Salem District of Tamil Nadu is having higher poverty issues. This block has high concentration of unprivileged sections namely Schedule castes and tribes (32.4\%), who historically possess poor assets and social-cultural obstacles to improve their livelihood and life style.

Ayodhyapattinam block is also known for dry land based agriculture. Here the monsoon uncertainties play havoc in their day to day activities. Hence, the project was funded by State Balanced Growth Fund, Tamil Nadu (SBGF) and implemented by Veterinary University Training and Research Centre, Salem at Chinngoundapuram village in Ayodhyapattinam block for the empowerment of tribal Women through desi chicken enterprise.

\section{Materials and Methods}

Ayodhyapattinam block is a revenue block of Salem district in Tamil Nadu. This revenue block consists of 32 panchayat villages. The Project area is located in Chinnagoundapuram village and it is located $9 \mathrm{KM}$ towards East from District headquarters Salem. There are around 150 families of Scheduled tribal population in Chinnagoundapuram and nearby Nochipatti area.

The project entitled "Empowerment of tribal women by developing desi chicken enterprise in Salem District was funded by State Balance Growth Fund, Tamil Nadu (SBGF) and implemented by Veterinary University Training and Research Centre, Salem at Chinngoundapuram village. A total of 50 poor tribal women were selected from Chinnagoundapuram village in Ayodhyapattinam block based on their income level and interest on rearing desi bird. The selected beneficiaries were formed into 5 common livelihood Groups.

The activities such as imparting training and technical guidance to the beneficiaries of the scheme, procurement and supply of inputs such as birds, cages, feed and egg incubator along with power back up was carried out by Veterinary University Training and Research Centre, Salem.

Each beneficiary were provided with 6 (1 Male +5 Female) desi birds at 3 months age along with one night shelter, $60 \mathrm{~kg}$ feed, feeder and one unit of community incubator with 600 eggs capacity along with power back up. Regular deworming and vaccination were carried out by the technical staff of Veterinary University Training and Research Centre, Salem in the study period. At the end of one year of the project the data were collected and statistically analyzed by adopting standard procedures as described by Snedecor and Cochran (1994).

\section{Results and Discussion}

Total number of birds alive at the end of one year was $3.88 \pm 0.10$ out of six birds supplied to each beneficiary. The overall bird mortality (\%) was $22.12 \pm 2.12$. The age (days) at laying first egg was $160 \pm 1.34$. The number of eggs produced per bird per cycle was $15 \pm$ 0.05 . The overall hatchability of eggs was $67.3 \pm 0.02$ percent, whereas the hatchability of eggs using incubator was $73.12 \pm 1.30$ percent. Monthly additional income per family was Rs. $1450 \pm 37$ (Table 1).

The constraints faced by the beneficiaries on rearing native chicken and while using the egg incubator were assessed by ranking the constraints listed in pretested Questionnaires. The major constraints ranked are listed in Table 2 (Fig. 1 and 2). 
Table.1 Assessment of performance of birds

\begin{tabular}{|l|l|c|}
\hline S.No & \multicolumn{1}{|c|}{ Parameters } & $\begin{array}{c}\text { Production performance of } \\
\text { birds* }\end{array}$ \\
\hline 1. & Total number of beneficiaries & 50 \\
\hline 2. & $\begin{array}{l}\text { Total number of birds distributed to the } \\
\text { beneficiaries }\end{array}$ & $300(5+1 * 50)$ \\
\hline 3. & $\begin{array}{l}\text { Total number of birds alive at the end of scheme } \\
\text { period }\end{array}$ & $3.88 \pm 0.10(50)$ \\
\hline $\mathbf{4 .}$ & Age at laying eggs (days) & $160 \pm 1.34$ \\
\hline $\mathbf{5 .}$ & Number of eggs produced per bird per cycle & $15 \pm 0.05$ \\
\hline 6. & Overall hatchability (\%) of eggs & $67.3 \pm 0.02$ \\
\hline 7. & Egg incubator users (\%) & $60.4 \pm 0.07$ \\
\hline $\mathbf{8 .}$ & Hatchability (\%) of eggs using egg incubator & $73.12 \pm 1.30$ \\
\hline 9. & Overall bird mortality (\%) & $22.12 \pm 2.12$ \\
\hline $\mathbf{1 0 .}$ & Monthly additional income per family (Rs.) & $1450 \pm 37$ \\
\hline
\end{tabular}

Table.2 Constraints analysis in desi bird rearing scheme

\begin{tabular}{|c|l|c|c|}
\hline S.No & \multicolumn{1}{|c|}{ Constraints } & Rank & Percentage (\%) \\
\hline 1. & Loss of chicks by attack of predators & I & 51 \\
\hline 2. & $\begin{array}{l}\text { Conflict among the beneficiaries while using } \\
\text { community egg incubator. }\end{array}$ & II & 36 \\
\hline 3. & Morality of birds due to diseases & III & 13 \\
\hline
\end{tabular}

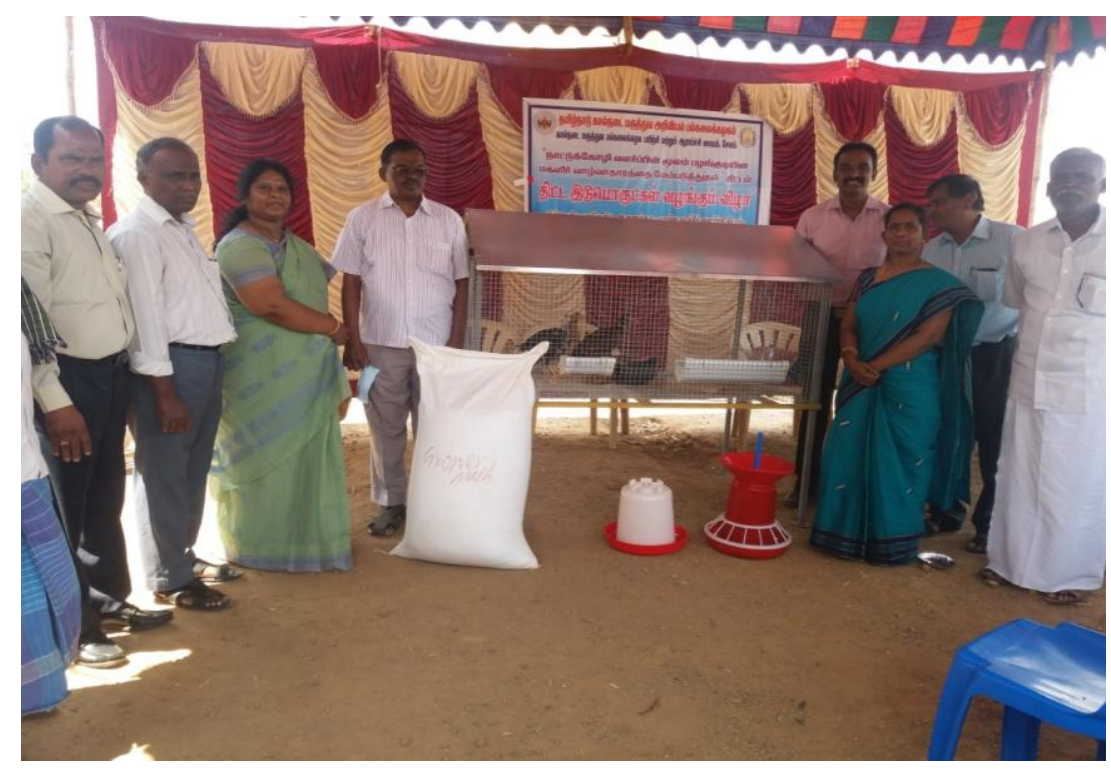

Fig.1 The scheme inputs distribution by the district level officials on 20.02.2017 at Chinnagoundapuram Village 


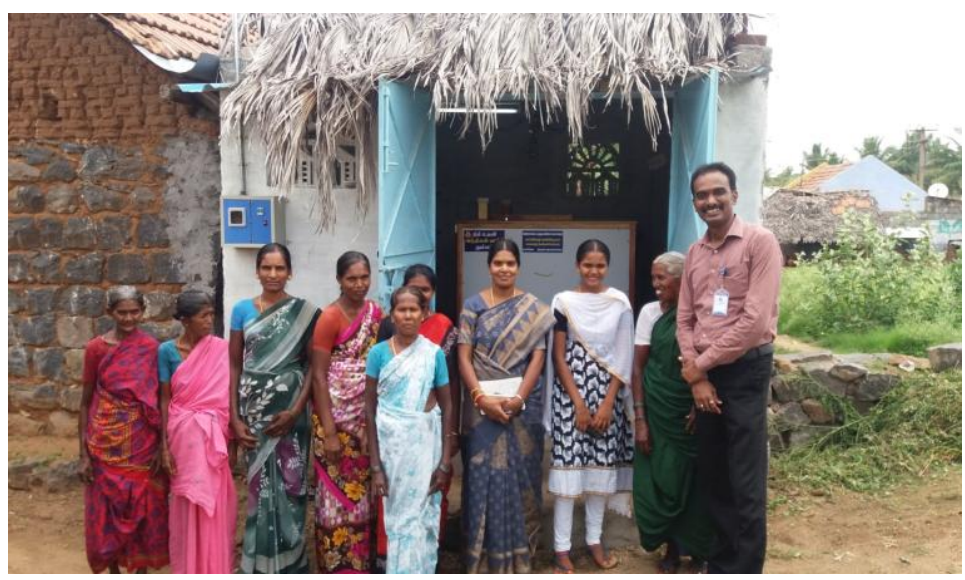

Fig.2 Beneficiaries with district planning officer in front of egg incubator room at Chinnagoundapuram on 13.06.2018

From this study, it can be inferred that supplementary income of tribal women is possible through desi birds rearing in backyard. Similar findings were also reported by Saha (2003) and Chaturvedani et al., (2015) on empowerment of tribal people through backyard poultry farming. It concluded that the desi bird rearing is a very much beneficial enterprise, ensuring additional regular income and plays the major role in empowering tribal women.

\section{References}

A K Chaturvedani, Niranjan Lal, Khalid, N K Khyalia and Jitendra Pratap, 2015. Empowering Tribal Women Through Backyard Poultry in Bastar District of Chhattisgarh. J Krishi Vigyan: 3: 19-22.

Ahuja V and Sen A (2007).Viability and future of small scale commercial poultry production in developing countries. Paper presented at International Conference on Poultry in the 21st Century: Avian Influenza and Beyond, Bangkok, November 5-7, 2007.

Jensen .H A. and Dolberg F. (2003). Essentials and constraints - Adaptation of the Bangladeshi smallholder poultry development concept. Paper presented at the workshop on "Management of research, communication and change within Agricultural Sector Programmes", held at Tune, Denmark, 31 March - 4 April. Pp. 5.

Jha. B.K and Asit Chakrabarti. 2017. International Journal of Agricultural Science and Research: 7: 267-274.

Mack, N., Woodsong, C., Macqueen, K. M., Guest, G. and Namey, E. (2005). Qualitative Research Methods: A Data Collector's Field Guide. Family Health International, North Carolina, USA.

Pica-Ciamarra, U. and Otte, J. (2010). Poultry, food security and poverty in India: Looking beyond the farm-gate. World's Poultry Science Journal, 66(2): 309-320.

Saha D (2003). Status of rural poultry production in North 24 Parganas district of West Bengal. M.V.Sc. Thesis, Indian Veterinary Research Institute, Izatnagar, Uttar Pradesh.

Snedecor, G.W. and W. G. Cochran, 1994 Statistical methods. 8 edition. Iowa State University Press, Ames, Iowa.

\section{How to cite this article:}

Sri Balaji, N., P. Ravi and Jayanthi, D. 2020. Empowerment of Tribal Women through Desi Chicken Enterprise in Ayodhyapattinam Block of Salem District in Tamil Nadu. Int.J.Curr.Microbiol.App.Sci. 9(05): 2427-2430. doi: https://doi.org/10.20546/ijcmas.2020.905.277 